\title{
MicroRNA-Mediated Inhibition of Amyloid Beta Protein Synthesis in Alzheimer's Disease: A Research Protocol
}

Katelyn R. Wang, HBSc Student [1]*, Will D. Jeong, HBSc Student [1], Alston Lo, HBSc Student [1], Kamron M. Zaidi, BASc Student [2]

[1] University of Toronto St. George, Toronto, Ontario, Canada M5S

[2] Department of Engineering, University of Toronto St. George, Toronto, Ontario,

Canada M5S

*Corresponding Author: katelyn.wang@mail.utoronto.ca

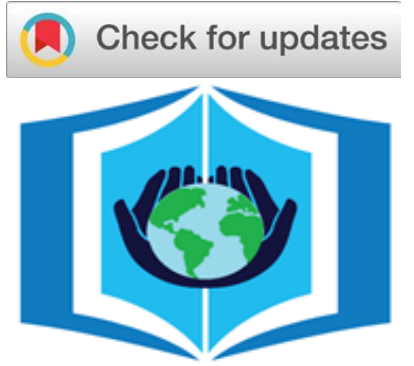

URNCST Journal

"Research in Earnest"

\begin{abstract}
Introduction: Alzheimer's disease (AD) is a currently incurable neurodegenerative disorder that is defined by the buildup of amyloid beta peptide (A $\beta$ ) plaques in the brain. Herein, we aim to investigate two microRNA (miRNA), miR-106b and miR-153, for their ability to inhibit the synthesis of amyloid beta precursor protein. Since miR-106b and miR-153 are also deficient in $\mathrm{AD}$ patients, we hypothesize that increasing their concentrations in the brain will reduce plaque development, thereby ameliorating $\mathrm{AD}$ symptoms.

Methods: Six groups of mice will be reared: a control group of healthy C57BL/6J mice; a control group of diseased B6. $\mathrm{Cg}-\mathrm{Tg}$ (Thy1-APP)3Somm/J mice; 2 control groups of B6.Cg-Tg(Thyl-APP)3Somm/J mice, one treated an empty miniosmotic pump, the other treated with functionless miRNA; and two treatment groups of B6.Cg-Tg(Thy1-APP)3Somm/J mice treated with miR-106b and miR-153 each. Then, a Morris water maze test and ELISA analysis will be conducted on each group to determine the effectiveness of the miRNA treatment at reducing $\mathrm{A} \beta$ plaque and $\mathrm{AD}$ symptoms.

Discussion: As a proof of concept study, this experiment may determine whether miRNAs can alleviate AD symptoms and plaque development. There may be limitations regarding the applicability of murine models, as well as the implementation of induced $\mathrm{AD}$ in the genetically modified mice. The results of each experimental group will be compared using an ANOVA, and qualitatively for improvement of cognitive functioning.

Conclusion: This experiment suggests an approach to counter the deleterious effects of AD. Future studies may investigate less invasive methods of administering miRNA treatments.
\end{abstract}

Keywords: Alzheimer's disease; microRNA; amyloid-beta; amyloid precursor protein; amyloid cascade hypothesis

\section{Introduction}

Alzheimer's disease (AD) is a devastating neurodegenerative disorder, characterized by personality changes, affective disturbances, memory loss, and a steady deterioration of mental function in patients [1]. Current treatments are symptomatic in nature, with medications such as cholinesterase inhibitors and memantine enhancing quality of life, despite having no effect on the progression of the disease [2]. AD is characterized by two aggregated proteins: amyloid beta protein $(\mathrm{A} \beta)$ and hyperphosphorylated tau [3]. The amyloid cascade hypothesis, which has been a dominant explanation of the pathogenesis of $\mathrm{AD}$, states that the accumulation and aggregation of $A \beta$ proteins is the initial event of the AD process [4-5].

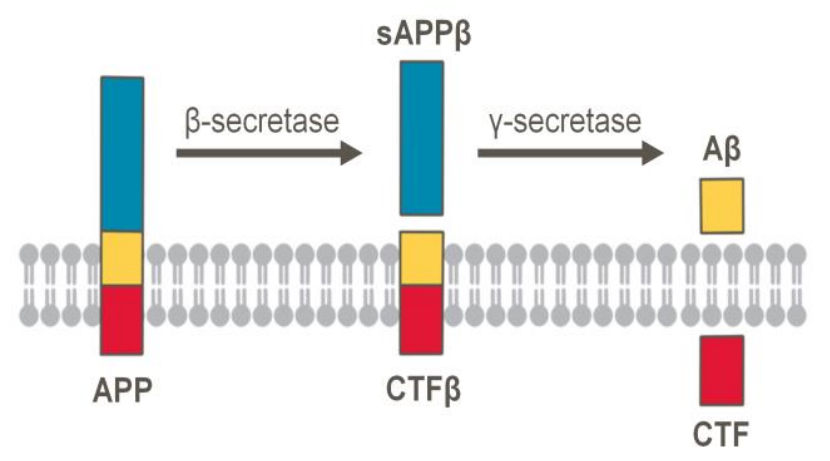

Figure 1. Amyloidogenic pathway [5]. 
UNDERGRADUATE RESEARCH IN NATURAL AND CLINICAL SCIENCE AND TECHNOLOGY (URNCST) JOURNAL Read more URNCST Journal articles and submit your own today at: https://www.urnest.com

$\mathrm{A} \beta$ is produced by the cleavage of amyloid precursor protein (APP) by a protease named $\beta$-secretase, producing two fragments, soluble amyloid precursor protein- $\beta$ (SAPP $\beta$ ) and CTF $\beta$ [5]. The latter is then cleaved by the protein complex $\gamma$-secretase, producing $\mathrm{CTF}$ and $\mathrm{A} \beta$ (Figure 1) [5]. A $\beta$ ultimately results in the formation of senile plaques, which may induce the phosphorylation of tau protein. Because of the important role $\mathrm{A} \beta$ plays in $\mathrm{AD}$, research into the reduction of $A \beta$ in the brain may prove useful in the development of a treatment for AD.

Recently, considerable focus has been placed on the potential role of microRNA (miRNA) in AD. miRNAs are a class of short non-coding RNA that, using a short "seed" region, can bind to complementary base pairings in a target mRNA to regulate gene expression [7-8]. Previous studies have identified miRNAs that translationally repress amyloid precursor protein (APP) mRNA or downregulate $\beta$-secretase [9-11]. Other miRNAs have been found to participate in $A \beta$ production, degradation, and $A \beta$-induced neurological damage [10]. However, studies have yet to quantify the extent of $A \beta$ reduction following the prolonged administration of select miRNA, or the effect this treatment has on the memory and spatial awareness of mice. To address this gap in the literature, we propose a study that investigates the augmentation of miRNA levels as an $\mathrm{AD}$ treatment. We will select miRNAs previously observed to inhibit APP production, and inject them into transgenic mice models. Subsequently, an enzyme-linked immunosorbent assay (ELISA) and Morris water maze (MWM) test will be used to evaluate the efficacy of the treatment. ELISA can be used to measure the concentration of $A \beta$ proteins, specifically $A \beta 40$ and $A \beta 42$, in the brain to determine if the miRNA treatment was effective in reducing inhibiting $A \beta$ synthesis, and the MWM can be used to assess the cognitive ability of the mice [12]. According to the amyloid cascade hypothesis, a high $\mathrm{A} \beta$ concentration in the brain is associated with AD. Therefore, we hypothesize that augmenting the amount of select miRNAs in the brain will inhibit $A \beta$ production, and in turn, reduce plaque development and ameliorate $\mathrm{AD}$ symptoms. Amongst the possible APP-inhibiting miRNA, miR-106b and miR-153 were selected as they consistently demonstrated reduced APP levels across multiple studies [9-11]. For example, Hébert et al. [9] observed a strong correlation between the expression of APP and miR-106b in cortical neurons from embryonic mice; and Liang et al. [10] found decreased expression of APP in the cerebral cortex of miR-153 transgenic mice. These miRNAs have also been administered to neuronal mice cells, making them especially desirable for this protocol [9-10].

If demonstrated to be effective, this miRNA treatment may hinder the progression of $\mathrm{AD}$, as reducing the concentration of $A \beta$ plaque in the brain may decrease neurological damage. Therefore, this study proposes a novel treatment option; since current established treatments are symptomatic in nature, a treatment leveraging miRNA would target the cause of the disease instead [13].

\section{Methods \\ Selection of miRNA}

Table 1. Modelling and effects of selected miRNA in previous studies.

\begin{tabular}{|l|l|l|}
\hline miRNA & Model & Effect \\
\hline miR-106b & $\begin{array}{l}\text { AD brain; HeLa } \\
\text { cells [9]. }\end{array}$ & $\begin{array}{l}\text { Decreased miR- } \\
\text { 106b expression } \\
\text { in AD brains; } \\
\text { reduction of } \\
\text { miR-106b is } \\
\text { correlated with } \\
\text { upregulation of } \\
\text { APP levels [9]. }\end{array}$ \\
& & $\begin{array}{l}\text { miR-153 levels } \\
\text { were suppressed } \\
\text { at early and late } \\
\text { stages of AD; } \\
\text { miR-153 } \\
\text { downregulates } \\
\text { APP expression } \\
\text { miR-153 }\end{array}$ \\
& $\begin{array}{l}\text { APPswe murine } \\
\text { model, human } \\
\text { AD brain } \\
\text { specimen, } \\
\text { miR-153 } \\
\text { transgenic mouse } \\
\text { model [10-11]. }\end{array}$ \\
\hline
\end{tabular}

The selected miRNAs (Table 1) are chosen as they are observed to exist in depleted levels in AD patients [14]. In fact, among sporadic AD patients, low levels of mir-153 has been shown to contribute to the accumulation of $A \beta$ [14]. Mir-153 is also a negative regulator of APP expression. Moreover, mir-106b has been found to repress APP translation, via the binding of APP 3' UTR $[9,14]$.

\section{Animal Subjects \& Living Conditions}

Six experimental groups, labelled 1 to 6 , of mice will be reared. Group 1 mice entail the C57BL/6J strain (B6), which will be used as a standard wild-type. The B6.Cg$\mathrm{Tg}$ (Thy1-APP)3Somm/J mouse strain (APP23) will be used to express the mutant human APP gene KM670/671NL (APPswe) for groups 2-6; this transgene results in the sevenfold overexpression of APP [15-16]. As a result, incipient stages of $A \beta$ plaque development can be observed in mice after 6 months, rendering this a highly effective model to test [17].

The mice will be kept in separate plastic containers; under $22^{\circ} \mathrm{C}, 60 \%$ humidity, and a constant light-dark cycle (light on, 700-1900h) [18]. Food and water will be supplied ad libitum. All mice will be 3 months old at the start of the experiment, when deficits in cognition are first observed in APP23 mice [19-20]. All experimental procedures will be 
UNDERGRADUATE RESEARCH IN NATURAL AND CLINICAL SCIENCE AND TECHNOLOGY (URNCST) JOURNAL Read more URNCST Journal articles and submit your own today at: https://www.urnest.com

conducted in accordance with the regulations provided by the Canadian Council on Animal Care.

\section{Artificial miRNA Synthesis}

Table 2. miRNA candidate oligonucleotide sequences [21].

\begin{tabular}{|l|l|l|}
\hline miRNA & $\begin{array}{l}\text { Guide Strand (seed } \\
\text { region is bolded) }\end{array}$ & Passenger Strand \\
\hline $\begin{array}{l}\text { hsa- } \\
\text { miR- } \\
\text { 106b }\end{array}$ & $\begin{array}{l}5^{\prime} \\
\text { UAAAGUGCUGAC } \\
\text { AGUGCA GAU 3' }\end{array}$ & $\begin{array}{l}3^{\prime} \\
\text { UUUUCACGAAUGU } \\
\text { UACUU GUC 5' }\end{array}$ \\
\hline $\begin{array}{l}\text { hsa- } \\
\text { miR- } \\
\text { 153-3p }\end{array}$ & $\begin{array}{l}5^{\prime} \\
\text { UUGCAUAGUCAC } \\
\text { AAAGU GAUC 3' }\end{array}$ & $\begin{array}{l}\text { 3' } \\
\text { UACGUAUCACUAG } \\
\text { UCCUUU CCUU 5' }\end{array}$ \\
\hline
\end{tabular}

RNA oligonucleotides corresponding to the selected miRNA's guide and passenger strands will be synthesized via Integrated DNA Technologies' service [10]. These sequences will be retrieved from the miR database, shown in Table 2. Arroyo et. al.'s [13] procedure will be applied to synthesize the miRNA, but the control will use sequentially similar miRNA without the seed region. Thus, the control and treatment are structurally and chemically similar, but the control miRNA will not target mRNA.

\section{miRNA Delivery}

Cerebroventricular injection will be regulated through the use of mini-osmotic pumps (MOPs) and an ALZET brain infusion kit [22]. MOPs will be implanted at the point when mice are 3 months old, when cognitive deficits are first observed in APP23 mice [23]. This will allow for the continual injection of miRNA without need for excessive handling, and these pumps will be maintained over a period of 9 months. This method was selected over alternatives such as molecular trojan horses or active transporters, to ensure delivery of the miRNA treatment, so verification tests would not be needed to determine whether the miRNA reached the brain. Groups 3-4 will serve as a MOP variable control, in which the MOP in group 3 will be empty and the one for group 3 will be administering non-targeting miRNA oligonucleotides. The non-targeting miRNA will also serve as a negative control to determine possible biases in the expression of $A \beta$ arising from miRNA application [24]. As for groups 5 and 6 , their MOPs will be filled with miR$106 \mathrm{~b}$ and miR-153, respectively.

\section{ELISA Analysis}

Mice subjects will be sacrificed after various durations of miRNA administration: after 3, 6 and 9 months. Using the ELISA kit procedure outlined in Saito et al. [25], A $\beta 40$ and $A \beta 42$ concentrations in the brain can be measured for each subject.

Wang et al | URNCST Journal (2020): Volume 4, Issue 6 DOI Link: https://doi.org/10.26685/urnest.189

\section{Morris Water Maze Test}

The Morris water maze is a validated assessment and measure of hippocampally dependent spatial navigation and reference memory in mice [26]. Vorhees and Williams's [26] methodology will be used to measure cognitive function every 3 months after the initial dosage.

The maze will be a circular pool $(122 \mathrm{~cm}$ diameter $)$, with non-reflective, uniform, white, $60 \mathrm{~cm}$ tall interior walls. A circular platform $(12 \mathrm{~cm}$ diameter $)$ will be submerged $1 \mathrm{~cm}$ below the surface of the water. The platform will be hidden from view as the pool will be filled to a depth of $40 \mathrm{~cm}$ with opaque water, prepared by adding milk powder [18]. To serve as landmarks for navigation, sufficient constant distal cues will be added around the maze. At 6 months of age ( 3 months since the start of the experiment), the mice will first be trained in cued learning trials for a duration of one week (4 trials daily), where distal cues are removed and the platform is elevated out of the water. A cued learning trial ensures that the mice have the basic prerequisite understanding of the platform as their destination or objective.

Four trials, each $1 \mathrm{~min}$ in duration with $15 \mathrm{~s}$ breaks in between will be conducted daily, with semi-random starting positions, such that each configuration is relatively equal in difficulty (i.e. each trial is equidistant from the platform). If a subject fails to locate the platform, they will be placed on the platform for $15 \mathrm{~s}$, and proceed to the next trial. Tracking software (HVS Image) will be used to track the path length and time duration. Mice will be observed for sensorimotor impairments or a misunderstanding of the task, which manifests as abnormal thigmotaxis or swimming over the platform. This is to elucidate the effects of miRNA on brain function, particularly memory, in AD cases.

\section{Results}

\section{Timeline}

Start of Experiment (0 months): All mice will be 3 months old at the start of the experiment, in which cognitive deficits are first observed in APP23 mice [23]. Mini-osmotic pumps (MOPs) will be implanted at this time in groups 3-6 as a control or to maintain a continual injection of functional miRNA.

3 Months: All groups are tested with the Morris water maze test, and 1/3 mice from each group will be randomly sacrificed and analyzed via ELISA.

6 Months: Remaining groups are tested with the Morris water maze test, and $1 / 2$ of the remaining mice from each group will be randomly sacrificed and analyzed via ELISA.

9 Months: Remaining mice are tested with the Morris water maze test, as well as, sacrificed and analyzed via ELISA. All mice will be sacrificed by the end of the experiment. 
UNDERGRADUATE RESEARCH IN NATURAL AND CLINICAL SCIENCE AND TECHNOLOGY (URNCST) JOURNAL Read more URNCST Journal articles and submit your own today at: https://www.urncst.com

\section{Goals}

Through the results of this experiment, we seek to observe whether meaningful changes between miRNA treated and control mice exist, both in terms of physiological measures (volume of $A \beta$ in the brain), and behavioural metrics. Therefore, by comparing the performances in a Morris water maze test, the memory, cognition and overall health and activity of the mice can be evaluated. Moreover, the ELISA analysis will yield information regarding the volumes of $A \beta$ in the brain. Though a direct comparison between the mice's initial and final state is not possible (ELISA analysis requires sacrificing the mice specimen), by comparing the groups evaluated at different time points (i.e. 3 months, 6 months and 9 months), we hope to analyze the relationship of treatment volume and levels of $\mathrm{A} \beta$.

\section{Data Analysis}

Multiple student's t-tests will be performed to evaluate the difference between measured $A \beta$ concentrations in the brain in experimental groups 2-5 compared with group 1 (healthy mice, no treatment). The Holm-Bonferroni method will be utilized to correct issues related to multiple hypotheses tests. Furthermore, forest plots will display the data of each experimental group, organized by time (i.e. 3 months, 6 months, and 9 months). Therefore, the trend of $\mathrm{A} \beta$ concentrations over time and miRNA treatment volume may be visually depicted. The MWM results will be analyzed qualitatively and quantitatively in accordance with the procedure described by Vorhees and Williams [26]. MWM times will be expressed in terms of mean \pm standard deviation.

\section{Discussion}

Given that there is no precedent to determine intrinsic success, test groups will be compared for relative performance. If the treated groups demonstrate comparably improved memory and plaque levels, there is basis to suggest the viability of miRNA treatments.

\section{Limitations}

Many of the limitations present in this study stem from physiological differences between mice and humans that influence the pathology of AD. For example, the spatial distribution of $A \beta$ plaques is significantly different in mice, limiting the applicability of this model [27]. Furthermore, genetically inducing AD through the implementation of a mutated APP allele poses another limitation. This is as a treatment based on mutation induced $\mathrm{AD}$ may not be applicable to all patients given how AD is commonly associated with both environmental and genetic risk factors [28]. Despite these limitations, the key interaction between the human APP mRNA and miRNA is still present in the transgenic mice, making them a reasonable model [27].

Limitations regarding experimental techniques include the false positive rate associated with ELISA analysis due to insufficient blocking [12]. This may result in quantification errors in which $A \beta$ levels are lower than they appear. However, careful action and the use of negative controls should yield an adequately low false positive rate. Furthermore, a variety of noncognitive confounding variables separate from spatial memory and learning (ie. anxiety) may affect the performance of mice in the MWM test [29]. These variables have been estimated to constitute two-thirds of statistical variability, posing a potential problem when comparing the cognitive function of different mice. Despite this, the MWM still considers a variety of cognitive factors and confounding variables exist in every behavioural test regardless [29].

\section{Adverse Effects}

Though this treatment seeks to depress APP production via miRNA inhibition, APP is associated with a variety of physiological processes. These processes include synaptic adhesion, intracellular signalling, and axon pruning amongst others [30]. As a result, higher miRNA dosages are not necessarily better; instead, the trade-off between efficacy and safety should be carefully considered when finding the optimal dosage. Another possible consequence of this treatment is the excessive inhibition of miR-106b and miR-153's other targets aside from the APP gene, resulting in the underexpression of countless proteins [31]. A potential solution to this concern would be the administration of multiple APP-targeting miRNA at lower concentrations, reducing the risk of any one miRNA being overexpressed while still downregulating APP.

\section{Alternative Hypotheses}

While the amyloid cascade hypothesis is the mainstream explanation for the pathogenesis of $\mathrm{AD}$, various other hypotheses have been suggested since its establishment. Of these, the tau hypothesis is the most prominent and suggests that hyperphosphorylated tau aggregations are the primary substance responsible for AD. As abnormal tau can convert normal tau to an abnormal type, it is thought that tauopathy originates in a small number of nerve cells and then spreads to others [32]. Though this transfer is still not fully understood, strong evidence suggests that APP facilitates this transfer [33]. As the miRNA delivered targets APP as opposed to other proteins involved in the formation of $A \beta$, this treatment would inhibit the propagation of tau and thus slow down the progression of $\mathrm{AD}$, even if the tau hypothesis is correct.

\section{Conclusions}

This study proposes a potential approach to treating $\mathrm{AD}$ through the use of miRNAs to target APP and reduce $A \beta$ concentrations in the brain. To determine the efficacy of this treatment, MOPs will be used to deliver miR-106b and miR-153, two miRNAs that depress APP production, to the brain of B6.Cg- $\mathrm{Tg}$ (Thy1-APP)3Somm/J strain mice. This strain will be used to express the mutant human APP gene 
UNDERGRADUATE RESEARCH IN NATURAL AND CLINICAL SCIENCE AND TECHNOLOGY (URNCST) JOURNAL Read more URNCST Journal articles and submit your own today at: https://www.urncst.com

KM670/671NL (APPswe), which results in an increase in APP expression. Using ELISA and MWM, the concentration of $\mathrm{A} \beta$ in the brain and cognitive function of the mice can be assessed and compared to control groups. If the experimental results support our hypothesis, then the tested miRNAs would alleviate symptoms and slow down the progression of AD. Future experimentation could further develop and refine this miRNA-based treatment. For instance, less invasive miRNA delivery mechanisms can be examined, such as utilizing focused ultrasound with microbubbles [34]. Additionally, other miRNA candidates may be tested, and the miRNA dosage concentrations can be optimized. Moreover, any potential side effects can be further explored. Nonetheless, this treatment potentially offers a prospective approach of slowing or halting the progression of $\mathrm{AD}$, and therefore has the potential to improve the lives of $\mathrm{AD}$ patients.

\section{List of Abbreviations Used}

AD: Alzheimer's disease

A $\beta$ : amyloid beta peptide

miRNA/miR: microRNA

APP: amyloid precursor protein

ELISA: Enzyme-Linked Immunosorbent Assay

MWM: Morris water maze

mRNA: messenger RNA

MOP: mini-osmotic pumps

\section{Conflicts of Interest}

The authors declare that they have no conflict of interests.

\section{Ethics Approval and/or Participant Consent}

No REB review was required as this paper is a proposal, not primary research.

\section{Authors' Contributions}

KRW: made contributions to the design of the final study, drafted and revised the manuscript carefully, and gave final approval of the version to be published.

WDJ: made contributions to the design of the final study, drafted and revised the manuscript carefully, and gave final approval of the version to be published.

AL: made contributions to the design of the final study, drafted and revised the manuscript carefully, and gave final approval of the version to be published.

KMZ: made contributions to the design of the final study, drafted and revised the manuscript carefully, and gave final approval of the version to be published.

\section{Funding}

This study was not funded.

\section{References}

[1] Schachter AS, Davis KL. Alzheimer's disease. Dialogues Clin Neurosci. 2000 Jun;2(2):91-100. PubMed PMID: 22034442; PubMed Central PMCID: PMC3181599.

Wang et al | URNCST Journal (2020): Volume 4, Issue 6 DOI Link: https://doi.org/10.26685/urncst.189
[2] Weller J, Budson A. Current understanding of Alzheimer's disease diagnosis and treatment. F1000Res. 2018;7:1161. https://doi.org/10.12688/f1000research. 14506.1.

[3] Mann DMA, Hardy J. Amyloid or tau: the chicken or the egg? Acta Neuropathol. 2013 Aug 8;126(4):609-13.

[4] Selkoe DJ, Hardy J. The amyloid hypothesis of Alzheimer's disease at 25 years. EMBO Mol Med. 2016 Mar 29;8(6):595-608. https://doi.org/10.15252/ emmm.201606210.

[5] Panza F, Lozupone M, Logroscino G, Imbimbo BP. A critical appraisal of amyloid- $\beta$-targeting therapies for Alzheimer disease. Nat Rev Neurol. 2019 Jan 4;15(2):73-88. https://doi.org/10.1007/s00401-013$1162-1$

[6] Serpell LC. Alzheimer's amyloid fibrils: structure and assembly. Biochim Biophys Acta Mol Basis Dis. 2000 Jul 26;1502(1):16-30. https://doi.org/10.1016/S09254439(00)00029-6.

[7] Oliveto S, Mancino M, Manfrini N, Biffo S. Role of microRNAs in translation regulation and cancer. World J Biol Chem. 2017 Feb 26;8(1):45-56. https://doi.org/ 10.4331/wjbc.v8.i1.45.

[8] Orang AV, Safaralizadeh R, Kazemzadeh-Bavili M. Mechanisms of miRNA-Mediated Gene Regulation from Common Downregulation to mRNA-Specific Upregulation. Int J Genomics. 2014 Aug 10;2014:970607. https://doi.org/10.1155/2014/970607.

[9] Hébert SS, Horré K, Nicolaï L, Bergmans B, Papadopoulou AS, Delacourte A, et. al. MicroRNA regulation of Alzheimer's Amyloid precursor protein expression. Neurobiol Dis. 2009 Mar; 33(3):422-428. https://doi.org/10.1016/j.nbd.2008.11.009.

[10] Liang C, Zhu H, Huang L, Ma C, Deng W, Liu Y, et. al. MicroRNA-153 negatively regulates the expression of amyloid precursor protein and amyloid precursorlike protein 2. Brain Res. 2012 May 21;1455:103-113. https://doi.org/10.1016/j.brainres.2011.10.051.

[11] Long JM, Ray B, Lahiri DK. MicroRNA-153 physiologically inhibits expression of amyloid- $\beta$ precursor protein in cultured human fetal brain cells and is dysregulated in a subset of Alzheimer disease patients. J Biol Chem. 2012 Sep 7;287(37):3129831310. https://doi.org/10.1074/jbc.M112.366336.

[12] Xiao Y, Isaacs SN. Enzyme-linked immunosorbent assay (ELISA) and blocking with bovine serum albumin (BSA) - not all BSAs are alike. J Immunol Methods. 2012 Jun 18;384(1-2):148-51. https://doi.org/10.1016 /j.jim.2012.06.009.

[13] Arroyo JD, Gallichotte EN, Tewari M. Systematic design and functional analysis of artificial microRNAs. Nucleic Acids Res. 2014 May 14;42(9):6064-6077. https://doi.org/10.1093/nar/gku171.

[14] Wang M, Qin L, Tang B. MicroRNAs in Alzheimer's Disease. Front Genet. 2019 Mar 1;10:153. https://doi.org/10.3389/fgene.2019.00153. 
UNDERGRADUATE RESEARCH IN NATURAL AND CLINICAL SCIENCE AND TECHNOLOGY (URNCST) JOURNAL

Read more URNCST Journal articles and submit your own today at: https://www.urncst.com

[15] Mazen A, Jin HL. A guide to using functional magnetic resonance imaging to study Alzheimer's disease in animal models. Dis Model Mec. 2018 May 1;11(5):1-13. https://doi.org/10.1242/dmm.031724.

[16] Sturchler-Pierrat C, Abramowski D, Duke M, Wiederhold KH, Mistl C, Rothacher S, et. al. Two amyloid precursor protein transgenic mouse models with Alzheimer disease-like pathology. Proc Natl Acad Sci U S A. 1997 Nov 25;94(24):13287-13292. https://doi.org/10.1073/pnas.94.24.13287.

[17] Snellman A1, López-Picón FR, Rokka J, Salmona M, Forloni G, Scheinin M, et al. Longitudinal amyloid imaging in mouse brain with 11C-PIB: comparison of APP23, Tg2576, and APPswe-PS1dE9 mouse models of Alzheimer disease. J Nucl Med. 2013 Aug 1;54(8):1434-1441. https://doi.org/10.2967/jnumed.112 .110163 .

[18] Drapeau E, Mayo W, Aurousseau C, Le Moal M, Piazza PV, Abrous DN. Spatial memory performances of aged rats in the water maze predict levels of hippocampal neurogenesis. Proc Natl Acad Sci U S A. 2003 Nov 25;100(24):14385-14390. https://doi.org/ 10.1073/pnas.2334169100.

[19] Van Dam D1, D'Hooge R, Staufenbiel M, Van Ginneken C, Van Meir F, De Deyn PP. Age-dependent cognitive decline in the APP23 model precedes amyloid deposition. Eur J Neurosci. 2003 Jan 10;17(2):388-396. https://doi.org/10.1046/j.1460-9568 .2003.02444.x.

[20] Kelly PH, Bondolfi L, Hunziker D, Schlecht HP, Carver K, Maguire E, et. al. Progressive age-related impairment of cognitive behavior in APP23 transgenic mice. Neurobiol Aging. 2003 Mar-Apr;24(2):365-378. https://doi.org/10.1016/S0197-4580(02)00098-2.

[21] Wong N, Wang X. miRDB: an online resource for microRNA target prediction and functional annotations. Nucleic Acids Res [Internet]. 2015 [cited 2019 Nov 19];43(D1):D146-152. Available from: http://www.mirdb.org/.

[22] Yutaka I, Dongpei L and Robert KY. Intracerebroventricular Infusion of Gangliosides Augments the Adult Neural Stem Cell Pool in Mouse Brain. ASN Neuro. 2019 Oct 21;11:1-8. https://doi.org/10.1177/1759091419884859.

[23] Lipsman N, Meng Y, Bethune AJ, Huang Y, Lam B, Masellis M, et. al. Blood-brain barrier opening in Alzheimer's disease using MR-guided focused ultrasound. Nat Commun. 2018 Jul 25;9:2336. https://doi.org/10.1038/s41467-018-04529-6.

[24] Hébert SS, Horré K, Nicolaï L, Papadopoulou AS, Mandemakers W, Silahtaroglu AN, et. al. Loss of
microRNA cluster miR-29a/b-1 in sporadic Alzheimer's disease correlates with increased BACE1/beta-secretase expression. Proc Natl Acad Sci U S A. 2008 Apr 29;105(17):6415-6420. $\quad$ https://doi.org/10.1073/pnas .0710263105 .

[25] Saito T, Hisahara S, Iwahara N, Emoto MC, Yokokawa $\mathrm{K}$, Suzuki $\mathrm{H}$, et. al. Early administration of galantamine from preplaque phase suppresses oxidative stress and improves cognitive behavior in APPswe/PS1dE9 mouse model of Alzheimer's disease. Free Radic Biol Med. 2019 Dec;145:20-32. https://doi.org/10.1016/j.freeradbiomed.2019.09.014.

[26] Vorhees CV, Williams MT. Morris water maze: procedures for assessing spatial and related forms of learning and memory. Nat Protoc. 2006 Jul 27;1(2):848858. https://doi.org/10.1038/nprot.2006.116.

[27] Sasaguri H, Nilsson P, Hashimoto S, Nagata K, Saito T, Strooper BD, et al. APP mouse models for Alzheimers disease preclinical studies. Embo J. 2017 Aug 1;36(17):2473-2487. https://doi.org/10.15252/embj 201797397.

[28] Gatz M, Reynolds CA, Fratiglioni L, Johansson B, Mortimer JA, Berg S, et al. Role of Genes and Environments for Explaining Alzheimer Disease. Arch Gen Psychiat. 2006 Feb;63(2):168. https://doi.org/10 .1001/archpsyc.63.2.168.

[29] Wolfer DP, Stagljar-Bozicevic M, Errington ML, Lipp H-P. Spatial Memory and Learning in Transgenic Mice: Fact or Artifact? Physiology. 1998 Jun;13(3):118-123. https://doi.org/10.1152/physiologyonline.1998.13.3.118.

[30] Muller UC, Zheng H. Physiological Functions of APP Family Proteins. Cold Spring Harb Perspect Med. 2012 Feb;2(2):a006288. https://doi.org/10.1101/cshperspect a006288.

[31] Bartel DP. MicroRNAs: Target Recognition and Regulatory Functions. Cell. 2009 Jan 23;136(2):215233. https://doi.org/10.1016/j.cell.2009.01.002.

[32] Kametani F, Hasegawa M. Reconsideration of Amyloid Hypothesis and Tau Hypothesis in Alzheimer's Disease. Front Neurosci. 2018 Jan 30;12:25. https://doi.org/10.3389/fnins.2018.00025.

[33] Takahashi M, Miyata H, Kametani F, Nonaka T, Akiyama H, Hisanaga S-I, et al. Extracellular association of APP and tau fibrils induces intracellular aggregate formation of tau. Acta Neuropathologica. 2015 Apr 14;129(6):895-907. https://doi.org/10.1007 /s00401-015-1415-2.

[34] Yiannopoulou KG, Papageorgiou SG. Current and future treatments for Alzheimer's disease. Ther Adv Neurol Disord. 2012 Oct 5;6(1):19-33. https://doi.org/10 $\underline{.1177 / 1756285612461679 .}$. 
UNDERGRADUATE RESEARCH IN NATURAL AND CLINICAL SCIENCE AND TECHNOLOGY (URNCST) JOURNAL Read more URNCST Journal articles and submit your own today at: https://www.urncst.com

\author{
Article Information \\ Managing Editor: Jeremy Y. Ng \\ Peer Reviewers: Sera Whitelaw, Sumeya Mukhtar \\ Article Dates: Received May 11 20; Accepted Jun 17 20; Published Jul 1320
}

\title{
Citation
}

Please cite this article as follows:

Wang KR, Jeong WD, Lo A, Zaidi KM. MicroRNA-mediated inhibition of amyloid beta protein synthesis in Alzheimer's disease: A research protocol. URNCST Journal. 2020 Jul 13: 4(6). https://urncst.com/index.php/urncst/article/view/189

DOI Link: https://doi.org/10.26685/urncst.189

\section{Copyright}

(C) Katelyn R. Wang, Will D. Jeong, Alston Lo, Kamron M. Zaidi. (2020). Published first in the Undergraduate Research in Natural and Clinical Science and Technology (URNCST) Journal. This is an open access article distributed under the terms of the Creative Commons Attribution License (https://creativecommons.org/licenses/by/4.0/), which permits unrestricted use, distribution, and reproduction in any medium, provided the original work, first published in the Undergraduate Research in Natural and Clinical Science and Technology (URNCST) Journal, is properly cited. The complete bibliographic information, a link to the original publication on http://www.urncst.com, as well as this copyright and license information must be included.
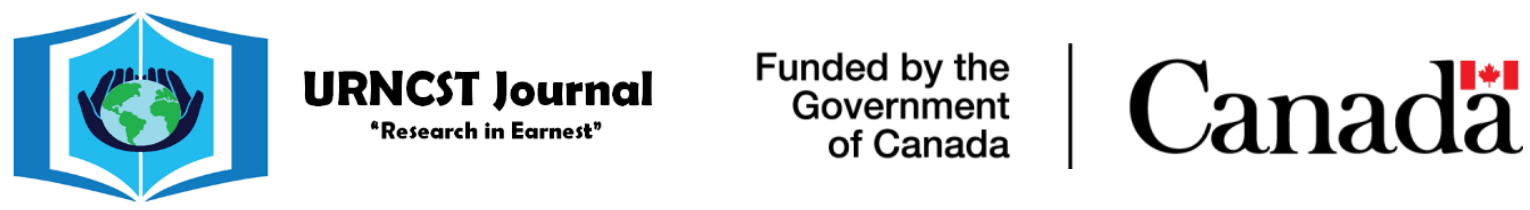

Do you research in earnest? Submit your next undergraduate research article to the URNCST Journal!

| Open Access | Peer-Reviewed | Rapid Turnaround Time | International | | Broad and Multidisciplinary | Indexed | Innovative | Social Media Promoted |

Pre-submission inquiries? Send us an email at info@urncst.com | Facebook, Twitter and LinkedIn: @ URNCST

Submit YOUR manuscript today at https://www.urncst.com! 